\title{
Work environment risk indicators for pharma- cists in the preparation of extemporaneous medicines
}

\author{
Zenija Roja $^{1}$, Henrijs Kalkis ${ }^{2}$, and Agnese Melluma ${ }^{1}$ \\ ${ }^{1}$ University of Latvia, Ergonomics Research Centre, Riga, Latvia \\ ${ }^{2}$ University of Latvia, Faculty of Business, Management and Economics, Department of management, \\ Riga, Latvia
}

\begin{abstract}
The pharmaceutical sector is one of the leading sectors of the Latvian economy, but the extemporary prepared medicines still occupy a small market share. The study involved 44 pharmacists and pharmacist assistants preparing extemporal medicines, while the control group included pharmacists and pharmacist assistants who only attend customers in pharmacies. The aim of this study was to identify work environment risk indicators for pharmacists preparing extemporal medicines in open-type pharmacies. In the research, we used methods of observation and survey to identify the views of pharmacists and pharmacist assistants preparing medicines in open-type pharmacies. The study concluded that pharmacists and pharmacist assistants who prepare medicinal products in open type pharmacies are exposed to a wide range of work environment risks, especially to the chemical risks. During our investigation, we identified the main work environment risk indicators: occupational accidents, workload, lack of information, exposure to chemicals, length of service, work environment quality, and use of personal protective equipment.
\end{abstract}

\section{Introduction}

The pharmaceutical sector is one of the leading sectors of the Latvian economy. Its added value per employee in manufacturing, wholesale, and retail trade significantly exceeds the average of the corresponding sector. For centuries, from Hippocrates' times to the 20th century, all doctors' prescriptions, including plant extracts, pills and ointments, were made in a pharmacy. Such preparation of medicines fell sharply in the mid-20th century, when extensive industrial drug production started [1]. In recent years, extemporaneous drug preparation (EDP) has begun to experience a revival, particularly in dermatology [1,2]. Extemporaneous preparation in a classical sense is a preparation of medicines in a pharmacy for a particular patient following an individual doctor's prescription [3]. This includes creating medicines by changing already existing medicines or by creating a completely new combination of raw ingredients [4]. EDP's main goal is to meet the patient's needs for a cure that is not available commercially [1].

In Latvia, extemporary prepared medicines still occupy a small market share, for example, in 2017 they represented $0.65 \%$ of the total market value of prescription and non-prescription medicines [5]. In other countries, however, for example, U.S. extemporal drug forms account 
for 1-2\% of all medicines delivered [1]. A study by Staubach et al. shows that in Germany $30 \%$ of prescriptions in dermatology are extemporary prepared, while they account for a little over half $(53.5 \%)$ of all extemporaneous prescriptions [2].

Pharmacists and pharmacist assistants (P/PA) prepare medicines in pharmacies and, like other healthcare professionals, are exposed to a wide variety of occupational risks, but specifically to chemical risks (acids, alkali and solvents, etc., or mixtures thereof), which are the main risks in the pharmaceutical industry. P/PA work on exposed working surfaces with a variety of medicinal products, e.g. in powdered form; they are poured onto the scales, crushed in mortar, and mixed. Particles of crushed powders spread across the room and even across the pharmacy, creating occupational exposure risks for employees [6-9]. As a result, pharmacy workers may develop a variety of health problems. Studies have shown, for example, that $71.3 \%$ of women - pharmacists believe that after starting work in the preparation of medicines in an open-type pharmacy noticed some of the specific symptoms of the substance [10].

The employee can notice the acute effects and minimize them as far as possible. Scientists think that hazardous are those health risks that appear only after a longer period several years after the contact, like cancer $[11,12]$. The fact that various drug substances are able to cause cancer became familiar in the $1970 \mathrm{~s}$ of the 20th century. Long-term animal tests were initiated to determine whether the substance is carcinogenic or not [13]. Worldwide, it is considered that $3-6 \%$ of all cancer cases are acquired in the workplace where the worker is exposed to carcinogenic agents [14]. The National Institute for Occupational Safety and Health (NIOSH) consider as dangerous those medicinal products that have been proven dangerous to humans or animals: carcinogenic, genotoxic, teratogenic, toxic to reproductive system, toxic to organs in low doses, as well as new medicines that are similar to those already listed in terms of structure and toxicity. It is estimated that around 8 million U.S. medical employees (including pharmacists) are likely to be subjected to occupational exposition of dangerous medicines, both those involved in the preparation and administration of the medicine to the patient and those working in the medical establishments [15] where the drug is being used.

Scientific publications of recent years focus only on the safety of extemporary prepared medicines from a patient perspective, as well as on the occupational health of workers preparing particularly hazardous drugs (e.g., for chemotherapy) in closed-type pharmacies.

Therefore, the aim of this study was to identify work environment risk indicators for pharmacists preparing extemporal medicines in open-type pharmacies. The study involved pharmacists and pharmacist assistants preparing extemporal medicines, while the control group included pharmacists and pharmacist assistants who only attend customers in pharmacies.

\section{Material and methods}

\subsection{Study base - material}

The study involved 44 pharmacy workers from one of the leading pharmacy networks in Latvia - women aged between 20 and 59, with a length of service between 1 and 39 years. The selection criteria was: no acute health problems related to the preparation of medicinal products or work in pharmacies, full consent to participate in the study, registered in pharmacist and pharmacist assistant register. The exclusion criteria were acute symptoms of chemical risk exposure, and having not been to mandatory medical examinations. In the research, for practical investigation four open-type pharmacy premises were selected. In each open-type pharmacy, there were two medicinal product preparation rooms and one customer service hall. 
Table 1. Main demographic description of the study group and control group: mean age and range, mean height, mean weight, mean body mass index (BMI), standard deviation (SD).

\begin{tabular}{|c|c|c|c|c|c|c|c|}
\hline $\begin{array}{l}\text { Profession } \\
\text { /Length of } \text { service } \\
\text { (years) }\end{array}$ & $\mathbf{N}$ & $\begin{array}{l}\text { Mean length } \\
\text { of service } \pm \text { SD }\end{array}$ & $\begin{array}{l}\text { Mean } \\
\text { age } \pm \\
\text { SD }\end{array}$ & Range & $\begin{array}{l}\text { Mean height, } \\
\text { cm } \pm \text { SD }\end{array}$ & $\begin{array}{l}\text { Mean } \\
\text { weight, } \\
\mathrm{kg} \pm \mathrm{SD}\end{array}$ & $\begin{array}{l}\text { Mean } \\
\text { BMI, } \\
\mathrm{kg} / \mathrm{m}^{2} \pm \\
\text { SD }\end{array}$ \\
\hline $\begin{array}{l}\text { P/PA preparing } \\
\text { the medicinal } \\
\text { product }\end{array}$ & 22 & $8.41 \pm 8.09$ & $\begin{array}{l}34.27 \pm \\
11.09\end{array}$ & 20-59 & $166.27 \pm 6.19$ & $\begin{array}{l}70.27 \pm \\
8.11\end{array}$ & $\begin{array}{l}25.41 \pm \\
2.51\end{array}$ \\
\hline $1-4$ & 10 & $3.20 \pm 1.03$ & $\begin{array}{l}25.20 \pm \\
2.94\end{array}$ & $20-29$ & $164 \pm 8.41$ & $\begin{array}{l}65.40 \pm \\
8.29\end{array}$ & $\begin{array}{l}24.11 \pm \\
3.09\end{array}$ \\
\hline $5-9$ & 7 & $6.71 \pm 1.38$ & $\begin{array}{l}35.14 \pm \\
2.97\end{array}$ & $30-39$ & $166.86 \pm 4.26$ & $\begin{array}{l}72.14 \pm \\
6.04\end{array}$ & $\begin{array}{l}25.86 \pm \\
0.96\end{array}$ \\
\hline $10-19$ & 2 & $14.50 \pm 6.36$ & $\begin{array}{l}45.00 \pm \\
5.66\end{array}$ & $40-49$ & $167.50 \pm 2.12$ & $\begin{array}{l}78.00 \pm \\
2.83\end{array}$ & $\begin{array}{l}27.80 \pm \\
0.30\end{array}$ \\
\hline $20-30$ & 3 & $25.67 \pm 5.13$ & $\begin{array}{l}55.33 \pm \\
4.04\end{array}$ & $50-59$ & $168.67 \pm 2.52$ & $\begin{array}{l}77.00 \pm \\
3.00\end{array}$ & $\begin{array}{l}27.07 \pm \\
1.05\end{array}$ \\
\hline $\begin{array}{l}\text { P/PA attending } \\
\text { customers }\end{array}$ & 22 & $9.27 \pm 7.89$ & $\begin{array}{l}36.09 \pm \\
10.93\end{array}$ & 20-59 & $167.45 \pm 4.06$ & $\begin{array}{l}72.41 \pm \\
8.22\end{array}$ & $\begin{array}{l}25.76 \pm \\
2.08\end{array}$ \\
\hline $1-4$ & 7 & $3.14 \pm 1.07$ & $\begin{array}{l}14.43 \pm \\
3.21\end{array}$ & $20-29$ & $167.29 \pm 4.39$ & $\begin{array}{l}73.86 \pm \\
7.40\end{array}$ & $\begin{array}{l}26.33 \pm \\
1.59\end{array}$ \\
\hline $5-9$ & 9 & $6.78 \pm 1.39$ & $\begin{array}{l}35.44 \pm \\
2.30\end{array}$ & $30-39$ & $167.11 \pm 4.99$ & $\begin{array}{l}69.56 \pm \\
8.85\end{array}$ & $\begin{array}{l}24.82 \pm \\
2.03\end{array}$ \\
\hline $10-19$ & 3 & $15.00 \pm 3.74$ & $\begin{array}{l}45.67 \pm \\
2.05\end{array}$ & $40-49$ & $167.67 \pm 2.62$ & $\begin{array}{l}75.33 \pm \\
4.99\end{array}$ & $\begin{array}{l}26.77 \pm \\
1.14\end{array}$ \\
\hline $20-30$ & 3 & $25.33 \pm 5.03$ & $\begin{array}{l}55.67 \pm \\
2.52\end{array}$ & $50-59$ & $168.67 \pm 1.53$ & $\begin{array}{l}74.67 \pm \\
11.37\end{array}$ & $\begin{array}{l}26.20 \pm \\
3.55\end{array}$ \\
\hline
\end{tabular}

The analysis of workplaces was carried out during one working week cycle at different working day times in the preparation room.

\subsection{Observation and survey}

Mixed methods approach combining observation and survey was chosen in the research in order to understand contradictions between quantitative results (survey results) and qualitative findings (observation). We used the open observation method to identify working conditions of the pharmacists and pharmacist assistants in open type pharmacies. Authors developed protocol for structured observation in order to analyze obtained data. Each observation of the workplace per one worker was observed one time for 30 minutes and focus points were on work process, room and surface cleaning, personal protective equipment, workload, work environment, including general and local exhaust ventilation system. Observation results helped to develop survey questions. The survey was used to identify the views of pharmacists and pharmacist assistants preparing medicines in open-type pharmacies. They were asked to give their opinion on the existing chemical risks in the working environment, on the habits of usage of individual protective equipment, on the frequency of the most typical symptoms due to exposure to substances experienced during working days, on daily healthy and unhealthy habits (smoking, alcohol use), and on out-of-work physical activities and on holidays. The questionnaire was created in the form of closed questions (structured answer questions with pre-answers) with 17 questions in the Internet environment. The participants filled it in remotely. Of the 17 questions asked to the study group, 5 questions about the 
incidence of different symptoms were also raised to the control group, which included P/PA who are not involved in the preparation of medicines, but work in customer service. The descriptive statistical methods were used to analyse results.

\section{Results and discussion}

\subsection{Observation results}

The identified observations and conclusions on P/PA working conditions are summarized in Table 2.

For the control group pharmacists and pharmacist assistants who only attend customers in pharmacies the main working conditions were as follows: compulsory standing positions, work at the computer displays more than 2 hours per day, arranging medicines on the shelves, customer service, work with a cash register. In comparison with the P/PA who prepares medicinal products, control group does not have direct contact with open medicinal products.

\subsection{Survey results}

The survey involved $44 \mathrm{P} / \mathrm{PA}$ who prepare medicines and attend customers in open-type pharmacies. The survey results show that $45.5 \%$ of the surveyed participants are aged between

Table 2. Main demographic description of the study group and control group: mean age and range, mean height, mean weight, mean body mass index (BMI), standard deviation (SD).

\begin{tabular}{|c|c|c|}
\hline Indicator & Identified observations & Conclusions \\
\hline $\begin{array}{l}\text { Workload; } \\
\text { possible } \\
\text { occupational } \\
\text { exposure time } \\
\text { of chemicals }\end{array}$ & $\begin{array}{l}\text { - Employees in the preparation of medicinal products } \\
\text { are employed full-time }-8 \text { hours a day, of which } \\
\text { approximately } 1 \text { hour is spent in rest periods } \\
\text { - Work is intensive: } 30 \text { prescriptions are received per } \\
\text { day for the preparation of medicines }\end{array}$ & $\begin{array}{l}\text { - Employees are preparing } \\
\text { medicines throughout the work- } \\
\text { ing day in compulsory work } \\
\text { postures, resting only during rest } \\
\text { periods } \\
\text { - Workers are subjected to po- } \\
\text { tential occupational exposure to } \\
\text { substances nearly full working } \\
\text { day }\end{array}$ \\
\hline $\begin{array}{l}\text { Skills of } \\
\text { employees }\end{array}$ & $\begin{array}{l}\text { - Are familiar with the physical and chemical proper- } \\
\text { ties of the substances, are able to predict the compat- } \\
\text { ibility of the substances. Manage the potential health } \\
\text { risks of substances } \\
\text { - Accidental pouring or spilling over of substances } \\
\text { have not been recorded during observations } \\
\text { - Are very accurate, careful, maintain cleanliness and } \\
\text { order }\end{array}$ & $\begin{array}{l}\text { - Employees have high skills, } \\
\text { precision, job cleanliness }\end{array}$ \\
\hline $\begin{array}{l}\text { Placement of } \\
\text { furniture }\end{array}$ & $\begin{array}{l}\text { - The furniture is arranged along the walls. The cen- } \\
\text { tral part of the room is free. The room has no thresh- } \\
\text { olds. Electrical cables pulled along the walls without } \\
\text { crossing the places of employees' movement. Parts } \\
\text { of the standing containers are located above } 1.9 \mathrm{~m} \text {, so } \\
\text { employees must step after them. It is intended to have } \\
\text { a special, stable stepping bench }\end{array}$ & $\begin{array}{l}\text { - Safe working conditions are } \\
\text { provided. } \\
\text { - Carelessly stepping up and } \\
\text { holding the stand in hands } \\
\text { the employee may fall off the } \\
\text { stepping bench }\end{array}$ \\
\hline $\begin{array}{l}\text { Working } \\
\text { surfaces }\end{array}$ & $\begin{array}{l}\text { - Surfaces are made of smooth, easy to clean and } \\
\text { washable material }\end{array}$ & $\begin{array}{l}\text { - When preparing medicines on } \\
\text { such surfaces, the safety of cus- } \\
\text { tomers and workers is respected }\end{array}$ \\
\hline
\end{tabular}




\begin{tabular}{|c|c|c|}
\hline $\begin{array}{l}\text { Working with } \\
\text { solids }\end{array}$ & $\begin{array}{l}\text { - Work is performed on exposed surfaces } \\
\text { - The powders and solids are poured from the larger } \\
\text { standing containers to the smaller ones } \\
\text { - In the preparation process, powders are weighed } \\
\text { then shifted into mortar, heavily grated and mixed } \\
\text { - The presence of medicinal products may be visually } \\
\text { established on the hands of pharmacists, e.g. protar- } \\
\text { gol is a dark substance, and during its grating the pres- } \\
\text { ence of flying particles can be found on employee's } \\
\text { hands and close working surfaces }\end{array}$ & $\begin{array}{l}\text { Within the work process } \\
\text { (weighing, mixing, grating), } \\
\text { powdered or crushed substances } \\
\text { may be inhaled with the airflow, } \\
\text { migrate around the room, con- } \\
\text { taminate surfaces. The airflow } \\
\text { may be generated by opening the } \\
\text { door or by the movements of the } \\
\text { employees themselves }\end{array}$ \\
\hline $\begin{array}{l}\text { Handling volatile } \\
\text { substances }\end{array}$ & $\begin{array}{l}\text { - Employees try to keep substances away from them- } \\
\text { selves, so they do not breathe their fumes } \\
\text { - The work is not done in the room with exhaust ven- } \\
\text { tilation system, so the presence of volatile substances } \\
\text { in the breathing area is felt }\end{array}$ & $\begin{array}{l}\text { - Effective local exhaust ventila- } \\
\text { tion is not provided }\end{array}$ \\
\hline $\begin{array}{l}\text { General } \\
\text { ventilation system }\end{array}$ & $\begin{array}{l}\text { - It is not effective since, for example, the prepared } \\
\text { "Antigripine" powder spreads through the working } \\
\text { room in the form of yellow deposits. Wet cleaning is } \\
\text { performed. A highly unpleasant aroma also spreads } \\
\text { to the trading room, e.g. by preparing ichthyol con- } \\
\text { taining ointments }\end{array}$ & $\begin{array}{l}\text { - It is necessary to install an ef- } \\
\text { ficient exhaust ventilation system } \\
\text { in the room in order to avoid con- } \\
\text { tact of workers with medicinal } \\
\text { products }\end{array}$ \\
\hline Use 0 & $\begin{array}{l}\text { - From PPE, only latex free gloves are used. During } \\
\text { the week, gloves were used once when preparing a } \\
\text { dye-containing solution }\end{array}$ & $\begin{array}{l}\text { PPE is not used regularly. It is } \\
\text { used only when working on skin- } \\
\text { colouring substances }\end{array}$ \\
\hline $\begin{array}{l}\text { Collection of pre- } \\
\text { scriptions and dis- } \\
\text { pensing of medici- } \\
\text { nal products }\end{array}$ & $\begin{array}{l}\text { - Pharmacists bring prescriptions into the drug prepa- } \\
\text { ration room ( } 30 \text { times per day) } \\
\text { - Pharmacists enter the drug preparation room to take } \\
\text { the finished medicines ( } 30 \text { times per day) } \\
\text { - Pharmacists enter the drug preparation room for ad- } \\
\text { vice ( } 10 \text { times per day) }\end{array}$ & $\begin{array}{l}\text { - Other pharmacy employees may } \\
\text { also inhale drug dust } \\
\text { - Possible transfer of drug dust to } \\
\text { other pharmacy rooms with em- } \\
\text { ployees' footwear } \\
\text { - Walking employees threaten air } \\
\text { cleanliness }\end{array}$ \\
\hline $\begin{array}{l}\text { Wet cleaning of } \\
\text { premises }\end{array}$ & $\begin{array}{l}\text { - Sanitary washing the floor and surfaces } 2 \text { times per } \\
\text { day - in the morning and at the end of the working } \\
\text { day } \\
\text { - Pharmacists or assistants wipe the working surface } \\
\text { after each product. Working surfaces are disinfected } \\
\text { regularly. Cleaning of wet surfaces is done several } \\
\text { times a day as needed }\end{array}$ & $\begin{array}{l}\text { - Wet cleaning of the room is } \\
\text { performed regularly }\end{array}$ \\
\hline
\end{tabular}

20 and 29, with a working experience of just 1-4 years. A study by Hanvold et al. shows that young employees are at greater risk of occupational accidents from workload, but are less likely to experience work-related diseases, and that the young employees, experiencing occupational exposure to chemicals, may have health problems working in the profession for a longer period [16]. At the same time, scientists believe that young employees are poorly aware of the risks of the working environment, and are adapting to the culture of the workplace for a long time. This leads to the conclusion that the younger employees are more likely to have occupational accidents (spilling over chemicals or their compounds, contact with powdered substances, tripping, etc.) than pharmacists or their assistants with a longer length of service. It suggests that two main risk indicators of the work environment are exposure to chemical risks and occupational accidents.

The survey also showed that $54.5 \%$ of the pharmacists surveyed thought their work was only slightly harmful in terms of chemical risks, and it did not actually cause them to worry. This suggests that pharmacists will not seek to protect themselves from harmful substances during work, which is contrary to studies by other authors. For example, a study by Marahatta et al. [17] shows that those employees who are aware of their occupational hazards are 3 
times more likely to apply safety measures to protect health at work, such as certain personal protective equipment (PPE - respirators, latex free gloves, etc.). Pharmacists were asked whether starting work they were familiar with the information provided in safety data sheets (SDS) regarding the safety of the chemical concerned. Of the respondents, $22.7 \%$ did not know anything about such sheets, $27.3 \%$ were familiar with the information provided by SDS on the substances used in the preparation of the medicinal product, while $45.5 \%$ with different regularity was acquainted with the information contained in the safety data sheets. Hence, authors conclude that another important risk indicator in the work environment is lack of information.

This leads to the conclusion that nearly $1 / 3$ of those surveyed are nevertheless familiar with the information provided by the SDS and can be regarded as having a positive attitude to their health. It does not coincide with the studies of other scientists, which show that, for example, of the 200 professional workers employed in the chemical industry, only $18 \%$ are familiar with information given in safety data sheets, and of 150 healthcare professionals $23 \%$ [18]. In other scientific studies, SDS are most often stored in the workplace with a view to meeting the requirement of the law rather than informing employees [19].

Nearly all those surveyed use latex-free gloves during work, $27.3 \%$ use goggles, and $31.8 \%$ - respirators. The results coincide with a study by Apatsidou et al. [18], which states that, in everyday practice, chemical workers working in the chemical industry use only gloves as PPE. On the question whether the employer had provided the relevant PPE, 17 participants (77.3\%) replied that they had been provided.

The determined low frequency of use of PPE corresponds to the data published by other authors, such as the report from the US Centre for Disease Control and Prevention [20]. It reports that in the observed pharmacy, where medicinal pills are repackaged according to a prescription, only some of the $>20$ employees wore gloves, but no one used protective clothing, goggles or respirator. Observations in the chemical industry [18] show that $25 \%$ of employees do not use PPE all, while a third of the workers using PPE do so only on the basis of the encouragement of the employer or the shift supervisor.

This could be explained by the fact that more than half of those surveyed believe that their work is not harmful. It also coincides with the results of other authors' studies [17]. The result is also supported by a study carried out in Iran [21] on small farmers' holdings, which do not use PPE during the spraying of pesticides. The authors of the study concluded that a large part of the workforce was not aware of usefulness and benefits of the use of PPE. However, those farmers who had been acquainted with handouts on the harm of pesticides to the health of workers, or those who saw benefits in the use of the PPE had significantly increased their willingness to start using the PPE in the future. This makes it possible to conclude that pharmacists and pharmacist assistants who prepare medicinal products need to be educated about the effects of chemicals or their compounds on the human body. They should know measures for health protection, including benefits of PPE in health promotion, in order to avoid symptoms, such as headache, dermatitis, throat irritation, etc., caused by chemicals. Authors conclude that use of PPE is a serious risk indicator in the work environment.

When comparing the survey results in the study and control group, it should be noted that pharmacists and pharmacist assistants who prepare medicinal products on a daily basis have a statistically higher incidence of hand skin irritation (e.g. redness, rash, itching, dermatitis) $(p=0.042)$ than pharmacists and pharmacist assistants in the control group (see Fig. 1).

However, differences between the study and control group in frequencies of symptoms such as: (1) nausea and vomiting, (2) headache, (3) cough and throat irritation, (4) expressed fatigue, somnolence and dizziness, are not statistically significant $(p=0.292, p=0.644, p=$ 0.126 and $p=0.929$, respectively). 


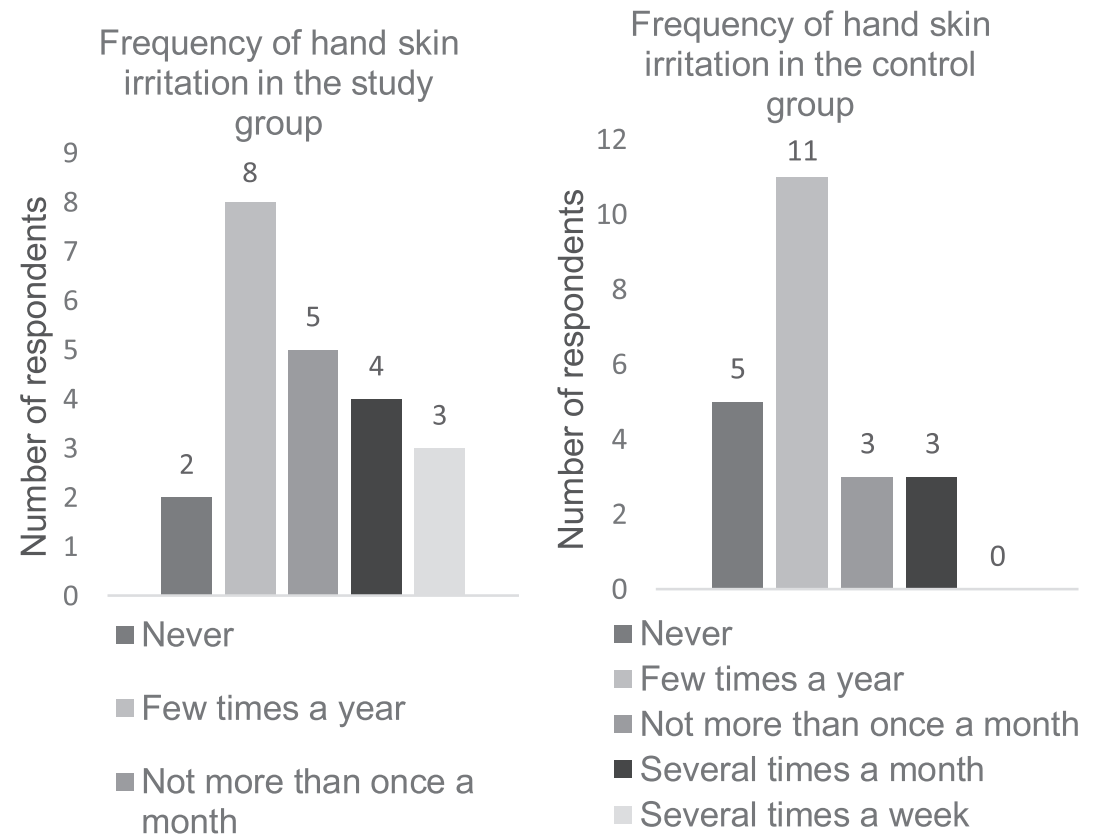

Figure 1. Opinion of the P/PA about the hand skin irritation comparing study and control group.

The acquired results showing the increased incidence of various skin irritations in $\mathrm{P} / \mathrm{PA}$ who prepare medicines are consistent with findings that employees of pharmaceutical production units often experience dermal problems related with occupational exposition (occupational contact dermatitis, caused by an irritant or allergen) (Winkler et al., 2015; Heron, 2003; Sherertz, 1994). Nevertheless, it should be noted that studies directly related to the pharmaceutical industry are very limited. In addition, the report by Alfonso et al. (2017) shows that skin diseases account for a significant proportion (40\%) of all occupational diseases in most European countries. The obtained results, showing that the other symptoms studied at work in those P/PA preparing medicinal products do not occur more frequently than in those P/PA not preparing medicinal products, are consistent with the study by Inaba et al. [10]. Nevertheless, it should be mentioned that their study did not demonstrate that dermal symptoms were significantly more frequent $(10.8 \%$ versus $6.6 \%$, $p=0.145$ ). However, the study of Inaba et al. [10] found that the nasal symptoms in those preparing medicines (hospital pharmacists involved in pill compression, capsule discharge, drug delivery, etc.) are statistically significant $(p<0.05)$ more frequently than in those $\mathrm{P} / \mathrm{PA}$ who do not prepare medicines. The lack of evidence of a difference in the incidence of other symptoms could be explained by the fact that nearly half of the employees surveyed have a limited length of service (1-4 years), and other symptoms can appear later [16].

Another risk indicator is work environment quality. For example, the view that the low performance of an outdated exhaust ventilation system could create subjective symptoms for an employee is consistent with the results of a study by scientists that the nasal symptoms were more frequently observed in employees working at hospital preparation and dispensing points, which are not equipped with adequate ventilation systems [10]. In a study on the existence of subjective symptoms among those $\mathrm{P} / \mathrm{PAs}$ preparing medicinal products in hospital 
and among those working in opened-type pharmacy it was found that, after starting work, the appearance of subjective symptoms was more frequent for those preparing medicinal products in an open-type pharmacy. The authors explain these results with a lower concentration of substances in the hospital, the reason of which should still be studied, but it could be assumed that the hospital has more efficient ventilation systems for collecting dust than the pharmacy. This assumption is implicitly confirmed by the study, which concluded that the presence of medicinal substances in the technological process is more observed where personnel perform operations manually on exposed surfaces, as well as by the fact that the concentration of substances evaluated in the air is closely linked to the effectiveness of the ventilation system [23]. The results of the Jung et al. [23] study also show that the contents of particles $\left(\mathrm{PM}_{2.5}\right.$ and $\left.\mathrm{PM}_{10}\right)$ are higher in hospital air in those hospitals where the ventilation system is provided through windows or single-split ventilation than where there is central air ventilation system.

The problem is also the accidental transmission of medicinal dust, contaminating other pharmacy rooms as well. Studies have shown the ability of drug substances to migrate and contaminate other surfaces, and further reach the hands of other employees, exposing them to risk. For example, a study in 5 different Canadian hospitals shows that many surfaces touched by personnel in one of the stages, from preparation to dispensing, are contaminated with antineoplastic drug (cyclophosphamide) particles. Examining a sample from employees' hands, the highest concentration of antineoplastic drugs was detected for an employee, who had not had any contact with cyclophosphamide at all. The presence of the substance on hands was also identified for employees (oncologist, volunteers, diet doctor, etc.) not involved in the administration of the medicines [24, 25].

\section{Conclusion}

Pharmacists and pharmacist assistants who prepare medicinal products in open type pharmacies are exposed to a wide range of work environment risks especially chemical ones. Hence during our investigation such main work environment risk indicators were identified: exposure to chemicals, workload, occupational accidents, lack of information, use of PPE, length of service, work environment quality. The study will be continued by using specialised methods for evaluating risk indicators in the work environment in order to objectively assess the presence of risks in the working environment of pharmacies, and to develop organisational and prevention measures in contemporary technological work environment.

This research has been supported by the project "Ergonomic stress indicators in contemporary technological work environment and possibilities of its improvement in social-technical system "HumanMachine-Environment'”, Agreement No. Nr.1.1.1.2/VIAA/3/19/546.

\section{References}

[1] J. Burch, Compounding Pharmacists Provide Customized Care. North Carolina Medical Journal 78(3), 191-194 (2017)

[2] P. Staubach, S. Salzmann, A. Peveling-Oberhag. Extemporaneous formulations in Germany - relevance for everyday clinical practice. Journal der DeutschenDermatologischen Gesellschaft (Journal of the German Society of Dermatology) 16(5), 566-574 (2018)

[3] A. Aquilina. The extemporaneous compounding of paediatric medicines at Mater Dei Hospital. Journal of the Malta College of Pharmacy Practice 19, 28-30 (2013) 
[4] D. Dubins, A. Laschuk, C. Ho. Extemporaneous Compounding in Pharmacy Practice. In: Encyclopedia of Pharmacy Practice and Clinical Pharmacy 418-451 (2019)

[5] O. Kiseḷova, B. Maurina, V. Šidlovska, J. Zvejnieks. The Extent of Extemporaneous Preparation and Regulatory Framework of Extemporaneous Compounding in Latvia. Medicina 55(9), 531 (2019)

[6] B. Prince, J. Lundevall. A growing codependency: compounding pharmacy and safety. International journal of pharmaceutical compounding 17(6), 485-489 (2013)

[7] K.W. Fent, S. Durgam, C. Mueller. Pharmaceutical Dust Exposure at Pharmacies Using Automatic Dispensing Machines: A Preliminary Study. Journal of Occupational and Environmental Hygiene 11(11), 695-705 (2014)

[8] R. Inaba, A. Hioki, Y. Kondo, H. Nakamura, M. Nakamura. Suspended particle and drug ingredient concentrations in hospital dispensaries and implications for pharmacists' working environments. Environmental Health and Preventive Medicine 21(2), 105-110 (2015b)

[9] O.G. Bhusnure, R.B. Dongare, S.B. Gholve, P.S. Giram. Chemical hazards and safety management in pharmaceutical industry. Journal of Pharmacy Research 12(3), 357-369 (2018)

[10] R. Inaba, A. Hioki, Y. Kondo, H. Nakamura, M. Nakamura. Prevalence of subjective symptoms among hospital pharmacists and association with drug compounding practices. Industrial health 53(1), 100-108 (2015a)

[11] E. Oddone, S. Negri, F. Morandi, M. Imbriani. Pharmaceutical Industries Air Quality. Comprehensive Analytical Chemistry 73, 589-621 (2016)

[12] W. Rühm, J. Breckow, G. Dietze, A. Friedl, R. Greinert, P. Jacob, S. Kistinger, R. Michel, W. Muêller, H. Otten, C. Streffer, W. Weiss. Dose limits for occupational exposure to ionising radiation and genotoxic carcinogens: a German perspective. Radiation and Environmental Biophysics 59(1), 9-27 (2020)

[13] G. Brambilla, F. Mattioli, L. Robbiano, A. Martelli. Update of carcinogenicity studies in animals and humans of 535 marketed pharmaceuticals. Mutation Research/Reviews in Mutation Research 750(1), 1-51 (2012)

[14] N.B. Hopf, C. Bolognesi, B. Danuser, P. Wild. Biological monitoring of workers exposed to carcinogens using the buccal micronucleus approach: A systematic review and meta-analysis. Mutation Research/Reviews in Mutation Research 781, 11-29 (2019)

[15] NIOSH (National Institute for Occupational Safety and Health) List of Antineoplastic and Other Hazardous Drugs in Healthcare Settings. https://www.cdc.gov/niosh/docs/2016-161/pdfs/2016-161.pdf?id10.26616/ NIOSHPUB2016161 (2016)

[16] T.N. Hanvold, P. Kines, M. Nykänen, S. Thomée, K. Holte, J. Vuori, M. Wærsted, K.B. Veiersted. Occupational safety and health among young workers in the Nordic countries: A systematic literature review. Safety and Health at Work 10(1), 3-20 (2018)

[17] S.B. Marahatta, S. Gautam, G. Paudel, U. Yadav. Awareness of occupational hazards and associated factors among automobile repair artisans in Kathmandu Metropolitan City, Nepal. Indian Journal of Occupational and EnvironmentalMedicine 22(1), 49-53 (2018)

[18] M. Apatsidou, I. Konstantopoulou, E. Foufa, K. Tsarouhas, P. Papalexis, R. Rezaee, D. Spandidos, D. Kouretas, C. Tsitsimpikou C. Safe use of chemicals by professionalusers and health care specialists. Biomedical Reports 8(2), 160-165 (2018)

[19] R.J. Willey. International Symposium on Safety Science and Technology Understanding a safety data sheet (SDS) in regards to process safety. Procedia Engineering 45, 857-867 
(2012)

[20] K.W. Fent, S. Durgam, M. Methner. CDC (Center of Disease Control and Prevention). Evaluation of pharmaceutical dust exposure at an outpatient pharmacy, Available at https://www.cdc.gov/niosh/hhe/reports/pdfs/2010-0078-3177.pdf (2013)

[21] M.S. Sharifzadeh, C.A. Damalas, G. Abdollahzadeh. Perceived usefulness of personal protective equipment in pesticide use predicts farmers' willingness to use it. Science of The Total Environment 609, 517-523 (2017)

[22] C. Champmartin, F. Clerc. Inhalable Dust Measurements as a First Approach to Assessing Occupational Exposure in the Pharmaceutical Industry. Journal of Occupational and Environmental Hygiene 11(2), 85-92 (2012)

[23] C.C. Jung, P.C. Wu, C.H. Tseng, H.J. Su. Indoor air quality varies with ventilation types and working areas in hospitals. Building and Environment 85, 190-195 (2015)

[24] C.Y. Hon, K. Teschke, W. Chu, P. Demers, S. Venners. Antineoplastic Drug Contamination of Surfaces Throughout the Hospital Medication System in Canadian Hospitals. Journal of Occupational and Environmental Hygiene 10(7), 374-383 (2013)

[25] C.Y. Hon, K. Teschke, W. Chu, P. Demers, S. Venners. Antineoplastic Drug Contamination on the Hands of Employees Working Throughout the Hospital Medication System. The Annals of Occupational Hygiene 58(6), 761-70 (2014) 